\title{
Chapter 13 \\ Environmental Citizenship in Secondary \\ Formal Education: The Importance of Curriculum and Subject Teachers
}

\author{
Niklas Gericke, Lihong Huang, Marie-Christine Knippels, \\ Andri Christodoulou, Frans Van Dam, and Slaven Gasparovic
}

\subsection{Curriculum Principles and Environmental Citizenship}

Teachers in formal secondary schools always teach based on the curricula of a school subject. In some countries they teach only one subject, in other countries perhaps two, three or even four. For instance, English science teachers are required to be able to teach biology, chemistry and physics to students aged 11-16. Overall, secondary schoolteachers are considered to be subject specialists, and their teaching is steered by what the formal curricula prescribes. The curricula of secondary school often consist of a general section that all teachers are obliged to follow and the

\footnotetext{
N. Gericke $(\bowtie)$

Department of Environmental and Life Sciences, Karlstad University, Karlstad, Sweden e-mail: niklas.gericke@kau.se

L. Huang

Youth Research Unit of NOVA - Norwegian Social Research, Oslo Metropolitan University, Oslo, Norway

e-mail: lihong.huang@oslomet.no
}

M.-C. Knippels

Freudenthal Institute, Utrecht University, Utrecht, The Netherlands e-mail: M.C.P.J.Knippels@uu.nl
A. Christodoulou
Southampton Education School, University of Southampton, Southampton, UK
e-mail: A.Christodoulou@ soton.ac.uk
F. Van Dam
Freudenthal Institute, Utrecht University, Utrecht, The Netherlands
e-mail: F.W.vanDam@uu.nl
S. Gasparovic
Faculty of Science, Department of Geography, University of Zagreb, Zagreb, Croatia
e-mail: slaveng@geog.pmf.hr


curricula or syllabi that prescribe what should be taught in each specific school subject. The issue of interest then, if we want to enact Environmental Citizenship in formal secondary education, is to identify instances within the curricula that cover the topics, teaching approaches and aims of Education for Environmental Citizenship. If it isn't included in the curriculum, Environmental Citizenship will most probably not be addressed by the teachers. In this chapter we will show how aspects of Environmental Citizenship are pinpointed in policy at a European level, and also give examples of the national curriculum in some countries.

Young and Muller (2010) identify two main trends or traditions in curricula development over the last decades. These traditions are extrapolated as trajectories into possible futures, denoted Future 1 and Future 2. According to Young and Muller (2010), a Future 1 perspective is characterised by a disciplinary content-driven curriculum where assessment is a focus. A problem with this curriculum principle is that it does not provide students with the knowledge to tackle complex problems of today's society (Young 2015). However, the Future 2 perspective suggests integrating school subjects, promoting generic skills and facilitative teaching. This perspective focuses on phenomena instead of concepts, which might be more relevant from a student's perspective but could lead to insufficient disciplinary knowledge to fully understand the phenomena according to Young (2015). To which trajectory does then Environmental Citizenship and Education for Environmental Citizenship relate? As can be seen in the chapters of this book, we would claim that it is more in line with a Future 2 tradition, i.e. Environmental Citizenship is focusing on environmental, economic and social issues of society, and the goal is to empower students as Environmental Citizens, with generic skills to enable them to counter environmental degradation.

Environmental Citizenship as an overarching construct, as outlined in this book, can often be found in the central goals of education, i.e. in the general curricula as a Future 2 perspective. Studies have shown that secondary teachers, in some countries at least, tend to focus on fulfilling the goals of the syllabi rather than looking at the overarching curricula that informs syllabi (Sundberg 2005). Hence, this could be one of the first hurdles or barriers to overcome if aspects of Environmental Citizenship are already part of the general curriculum. How can we support secondary schoolteachers to look beyond the core content of their subject syllabi so as to also address more general goals related to environment, sustainability and citizenship? Moreover, the disciplinary tradition of in-service teacher education programmes has been found to influence teachers to a high degree. In that way, the teaching approaches and selection of content relate to more traditional teaching rather than the progressive teaching approaches as suggested in environmental and sustainability education (Borg et al. 2012, 2014; Stables and Scott 2002). Hence, Education for Environmental Citizenship pedagogy that builds on student competencies for civic participation, contributing to environmental and social change, could be expected to render more resistance when implemented at secondary school in comparison to primary school.

A way to ensure that Education for Environmental Citizenship is addressed within formal education at the secondary school level is to include Education for 
Environmental Citizenship within existing school subjects. A school subject usually originates from a university discipline. Biology and mathematics are two typical examples of this. In contrast some school subjects do not exist at the university level; they are constructed for school to meet some important knowledge domains of society that do not stem from one discipline alone (Gericke et al. 2018). Civics, for example, is a subject that stems from both political science and national economy at university level. Another is natural science, a school subject that is taught in many countries drawing from biology, chemistry, physics and geoscience. Hence, finding aspects of Environmental Citizenship in different school subjects will illustrate different problems and/or opportunities, depending if the school subject is a 'miniature' of the disciplinary subject or if it is a construct of the school system, which inevitably will give more possibilities to include Environmental Citizenship perspectives from a Future 2 tradition. Another solution is to let Environmental Citizenship take the form of a specific subject in itself, but this requires political decision-making, and in most countries, it is a long-term goal.

Another aspect of secondary schooling is that lower secondary education in many countries is part of the compulsory school system aiming to foster literate citizens, while upper secondary schooling is voluntary and preparatory for further studies or a profession. If we use the categorisations of school aims developed by Biesta (2015), lower secondary school could be seen to aim at socialisation (to be able to understand and act within social practices), and subjectification (to be able to understand and create meaning), while upper secondary school aims at qualification (to be able to qualify for a further professional life). Hence, it will probably be easier to implement Education for Environmental Citizenship in lower secondary school because socialisation and subjectification are more in line with a Future 2 education. However, we need to stress that these are assumptions and could vary considerably depending on the country and the school system. In the following sections, we will elaborate on these issues.

\subsection{Environmental Citizenship in Policy and Curriculum}

Environmental Citizenship has been a constantly contested and evolving concept in multiple disciplines for decades (Pallett 2017). However, in recent years Environmental Citizenship has in fact become an integral element of civic and citizenship education curricula, both globally and at the European level (CoE 2018; Schulz et al. 2016). Most education systems in democratic societies have rather similar objectives of citizenship education, and in that, future citizens would be able to (i) interact effectively and constructively with others; (ii) be critical thinkers; (iii) act democratically; and (iv) act in a socially responsible manner. These objectives to a large extent relate to the socialisation goals of education (Biesta 2015). Hence, Environmental Citizenship at a curricular level follows the trajectory of a Future 2 perspective and can be seen as a response from the educational system to accommodate curricula due to changes in society. 
Out of the 42 national and local education systems existing in Europe, environmental protection is included in citizenship education curricula. This is used to build the student competence relating to 'acting in a socially responsible manner' in 21 systems at lower secondary education level, in 20 systems at upper secondary education level and in 19 secondary vocational education systems (European Commission/EACEA/Eurydice 2017). In most European education systems, citizenship education is taught integrated into other compulsory subjects except where citizenship education is taught as a separate compulsory subject in schools. At the same time, environmental activities for environmental awareness are on the rise among the top-level recommendations for extracurricular activities in 22 education systems at the secondary education level (European Commission/EACEA/Eurydice 2017). One conclusion is that if Environmental Citizenship is to be implemented in secondary formal schooling, it needs to be done through the curricula of many different school subjects and enacted by subject specialist teachers. This issue is at the centre of this chapter, and we will revisit this later on.

Another issue of concern is the importance of school organisation and school culture for including Education for Environmental Citizenship in secondary education (Fullan 2001). Previous studies on school leader perspectives concerning quality education in relation to education for sustainable development have identified four key factors that School principals recognise in order to achieve a transformation of education (Mogren and Gericke 2017):

First, collaborative interaction and school development, i.e. recognition that school development is an ongoing process where all the teachers and other co-workers of the school must actively participate.

Second, student-centred education, i.e. organisation of the education in alignment with students' needs, recognising that a good relationship between teachers and students is a sign of quality.

Third, cooperation with local society, i.e. recognition of the need for school organisations to cooperate with the local and global society.

Fourth, proactive leadership and continuity, i.e. a leadership style based on collective learning, implemented through the gradual progression of far-reaching plans.

Furthermore, it has been shown that it is important to have a common holistic vision between school leaders, teachers and students at the same school in order to transform education towards environmental and sustainable aims (Mogren et al. 2019).

In contrast, there are rather large discrepancies between school leadership, teachers and students on the view of how to implement environment citizenship education. The latest results from the international civic and citizenship education study (ICCS in 2016) in 24 countries (including 16 European countries) show that about one third $(38 \%)$ of school leaders consider 'promoting respect for and safeguarding the environment' as one of the most important aims of civic and citizenship education, while more than half $(51 \%)$ of the teachers agreed (Schulz et al. 2017). 
However, these numbers show a significant increase from previous results (ICCS in 2009 ) in 38 countries (including 24 European countries) where $31 \%$ of school leaders and $41 \%$ of the teachers considered 'promoting respect for and safeguarding the environment' as one of the most important aims of civic and citizenship education (Schulz et al. 2010). Among the European countries, we find that teachers and school leaders in Finland and Malta have the highest international average for the aim of 'safeguarding the environment', the most important aim of citizenship education, while those in Denmark, Estonia and Norway have the lowest.

School leaders have reported that a range of environmentally friendly practices have been adopted in their schools globally and across Europe (Schulz et al. 2017). Regarding differential waste collection practices, many students in Slovenia (99\%) and Belgium (95\%) reported upon such practices, while fewer students in Netherlands (51\%) and Estonia (55\%) reported the same. The variation between countries outside Europe is also large. In Taiwan, all of the students (100\%) report this practice, while the numbers in South America are under average for the study as a whole, i.e. Chile (30\%) and Mexico (59\%). In recognising that their schools have systems for waste reduction, students in Taiwan (99\%), in Slovenia (99\%) and in Finland (96\%) exercised this practice, with only $26 \%$ in the Netherlands, $38 \%$ in Denmark and $42 \%$ in Chile recognizing likewise. Regarding the issue of purchase of environment-friendly items, students in Taiwan (99\%) and Slovenia (88\%) reported the most frequent use of such practices, while only 34\% in Chile and 37\% of students in Netherlands reported likewise. Regarding the issue of communication, as high as $99 \%$ in Taiwan, $89 \%$ in Mexico and $95 \%$ of students both in Lithuania and in Slovenia are studying at a school where information posters that encourage students' towards environment-friendly behaviours are visible, while only $27 \%$ of students in Netherlands and 39\% of students in Sweden experience the same environmental communication in schools. From these examples, we can see that various countries globally and in Europe have very different school cultures relating to these issues, making the possibility for implementation of Education for Environmental Citizenship look very different depending on country and school culture.

The need for professional development in relation to Environmental Citizenship and Education for Environmental Citizenship is large, but also varies considerably between countries. Such professional development training seems more common in countries outside Europe; about $86 \%$ of teachers in Taiwan, $82 \%$ in Colombia and $76 \%$ in Mexico report such training, while, for example, only $41 \%$ of teachers in Belgium and $28 \%$ of teachers in Croatia have reported the same. Surprisingly though, over $80 \%$ of teachers of all countries feel confident in teaching subjects related to the environment and sustainability (Schulz et al. 2017). This contrasts quite heavily with other studies and countries where teachers often report a lack of experience and confidence (Borg et al. 2012).

In teaching practices of citizenship education, around $10 \%$ of teachers in all the participating countries have taken civic action-related initiatives with their students of 'writing letters to the newspapers or magazines to support actions about the environment', 'signing a petition on environmental issues' and 'posting on social 
network, forum, or blog to support actions about the environment' (Schulz et al. 2017). In secondary schools of countries from the Southern Hemisphere, e.g. Colombia (20\%), Mexico (21\%) and Peru (31\%), such teaching activities were found to be much more commonly reported then in many European countries, e.g. Belgium (3\%) and Sweden (3\%). Other more traditional teaching activities, to raise students' awareness of the environmental impact of excessive water and energy consumption, were however practiced to a similar degree in all countries and on average reported from $48 \%$ of the teachers (Schulz et al. 2017).

Many teachers in citizenship education seem to have a preparedness for Education for Environmental Citizenship, though they still are a minority of all teachers. This is also supported by school leader reports that claim that on average $61 \%$ of students in schools of the 24 participant countries of ICCS have participated in activities related to the environment or sustainability during a school year (Schulz et al. 2017). This view is reinforced by the fact that a majority of students (average $84 \%$ in 2009, and $86 \%$ in 2016) across the globe consider 'taking part in activities to protect the environment' as an important element of being a good adult citizen (Schulz et al. 2010, 2017).

In the following sections, we will go from the international level to three countries, England, Croatia and the Netherlands, and investigate the conditions set by the local curricula and school systems for implementing Environmental Citizenship and Education for Environmental Citizenship in formal secondary education. This way we will exemplify the possibilities and possible barriers for accomplishing this goal.

\subsubsection{The Case of England}

In England, Environmental Citizenship at secondary school level is not a concept that is explicitly addressed in the statutory requirements of the National Curriculum (NC) for Key Stage 3 (11-14-year-olds) and Key Stage 4 (14-16-year-olds). Instead, aspects of Environmental Citizenship are addressed through various subjects separately, mainly Science, Citizenship Education, and Geography. At Key Stage 4 (the last 2 years of formal schooling) under the tenet of 'Working Scientifically' (the section of the NC that outlines the scientific attitudes and skills that should be used and promoted through the subjects of Biology, Chemistry and Physics), students are expected to develop their scientific thinking skills of explaining everyday and technological applications of science; 'evaluating associated personal, social, economic and environmental implications; and making decisions based on the evaluation of evidence and arguments' (DfE 2015). This indirect curriculum focuses on the socioscientific issues and argumentation that shares common characteristics with Education for Environmental Citizenship. They both emphasise the need to consider the implications and applications of scientific knowledge to the environment and the actions needed in order to address them.

The subject of Citizenship Education focuses on developing students' knowledge and skills on a sociopolitical level so as to be able 'to take their place in society 
as responsible citizens' (DfE 2013a, p 1). For instance, students at Key Stage 4 (15-16 years old) should learn about 'the different ways in which a citizen can contribute to the improvement of their community, to include the opportunity to participate actively in community volunteering, as well as other forms of responsible activity' (DfE 2013a, p. 3). As Dobson (2007) discusses, aspects of Environmental Citizenship could be addressed through an Ecology or Environmental Citizenship lens. After the specification of Citizenship Education in 2013 was revised, more emphasis was placed on the subject of Citizenship Education from a political point of view, which mainly focused on students' understanding of 'democracy, government and the rights and responsibilities of citizens' (DfE 2013a, p. 2). With that, there is no direct mention of environmental issues or sustainability, although the active involvement and consideration of communities is explicitly considered. Perhaps closer to the aims of Education for Environmental Citizenship is the Geography specification for Key Stage 3, which states that students should 'understand how human and physical processes interact to influence and change landscapes, environments and the climate; and how human activity relies on the effective functioning of natural systems' (DFE 2013b, p. 2). However, since Geography is a non-compulsory subject, these opportunities are restricted to those students who choose to study it for their end-of-school exams (GCSEs). Furthermore, in the three subject specifications described in this section (Science, Citizenship Education, Geography), the combination of Environment, Citizenship and Action is not a concurrent requirement. As Glackin and King (2018a) emphasise, students are given few opportunities through curricula such as Science and Geography to be actively engaged and involved in environmental improvement. In their recent review of the state of environmental education in secondary schools in England, Glackin and King (2018b) point out that the place of environmental education is weak in current national policies in England, both from an ideological and structural perspective, which makes environmental education and Education for Environmental Citizenship much more challenging to implement within the English secondary school context. On the other hand, this points out the importance of inclusion of Education for Environmental Citizenship in the educational efforts.

As noted in Sect. 13.1, the fact that Environmental Citizenship is not an explicit component of a particular subject's curriculum makes it more challenging for secondary schoolteachers to address it in their teaching in England. This is due to a range of restrictive factors, which could include time, as well as the teachers' own subject knowledge of the related issues. For instance, if a citizenship teacher wished to address Environmental Citizenship dimensions, they would most likely need to have some understanding of scientific processes and science subject matter. Finally, education at Key Stage 4 is strongly framed based on qualification (Biesta 2015) with an increasing emphasis placed on the examinations students take at this stage, which can determine their post-compulsory education routes. This in combination with the emphasis placed on subject knowledge acquisition within environmental education currently (Glackin and King 2018b) means that fewer opportunities exist for the cross-curricular educational activities that would be required at the secondary school level for Education for Environmental Citizenship to be implemented. 


\subsubsection{The Case of Croatia}

When discussing Environmental Citizenship in secondary formal education and its implementation in Croatia, it is necessary to first describe how secondary education is organised. In Croatia, after 8 years of elementary school, children attend secondary school at the age of 14 or 15 and stay 4 years until they are 18 or 19 years old. Secondary schools in Croatia are divided into gymnasiums, vocational schools and art schools. Education in gymnasiums lasts 4 years. There are four available educational programmes: general (covers general education), science-mathematics (mathematics, informatics and science), classical (classics, Latin and Ancient Greek) and language (similar to general, but more oriented to foreign languages). Gymnasiums prepare students for tertiary education, and do not qualify students for a particular profession. Vocational schooling lasts 3 or 4 years, depending on the programme, and qualifies students for a particular profession. Art school takes 4 years to complete and aims to educate students in art and music. This school will not be addressed in this chapter because no subjects relating to Environmental Citizenship is taught in that programme. As can be seen from this summary, secondary education in Croatia is mostly framed from a qualification perspective (Biesta 2015) where the aim is to prepare the student for a profession or further study.

In the curriculum of secondary formal education in Croatia, Environmental Citizenship and Education for Environmental Citizenship are not used as specific terms. However, the curriculum of gymnasiums and vocational schools includes some courses and/or subjects that correspond to Environmental Citizenship and Education as Environmental Citizenship (NCEEE 2015). Similarly to the case in England, Environmental Citizenship is mostly part of the subject curriculum of Biology, both in gymnasiums and vocational secondary schools. Some aspects of Environmental Citizenship are also present in the Geography curriculum. However, some vocational secondary schools also include environmental education within some other subjects.

Within the gymnasium's curriculum in Biology, environment education is taught in fourth grade (last grade of the gymnasium). Students learn about ecology and the possibilities of the advancement and improvement of environmental protection. In geography, students learn about environment at the end of second grade after topics on demography, urban geography and economics. Furthermore, students learn about the interrelationship between human (and economic) activities and the environment. The basic difference between environmental education in biology and geography is the perspectives used: in Biology, the environment is presented through an ecosystem perspective, and in Geography through a spatial perspective. In both subjects, students are being educated about necessity of environment protection and how to be a responsible, pro-environmental-oriented citizen. Previously mentioned curriculum is valid for all gymnasium programmes. In the gymnasium programme of ScienceMathematics, Biology is being taught more extensively with practical training that is more in line with Education for Environmental Citizenship. Moreover, in ScienceMathematics gymnasiums, Ecology is offered as an optional subject where students are additionally educated about the environment and its importance in today's world. 
There are many various vocational secondary schools in Croatia, and Biology is usually taught for one or two years in these schools. In vocational secondary schools where Biology is taught for one year, Environmental issues are also being taught depending on a module that is officially valid in certain vocational school courses and regulated by documents of the Ministry of Education. This means that in some vocational secondary schools, environmental issues are not taught, and students have to rely on knowledge acquired in elementary school. However, these schools have Geography as part of their curriculum (some have even a 4-year curriculum), so students will be educated on some environmental issues but to less extent than in gymnasiums. It is important to recognise that in some vocational schools, an Ecological Technician course is available. This course is much more interrelated with ecology and environment, i.e. in line with Environmental Citizenship, so students will be educated in other activities that focus on the care and protection of nature and the environment.

In the Croatian education system, a programme called 'Citizenship upbringing and education' is also available (MSES 2014) that is more in line with a Future 2 perspective, emphasising socialisation and subjectification as learning goals. This programme consists of several themes, which are aimed to be integrated through inter-subject themes, advisory sessions and extra-classroom activities. One of these themes is 'Ecological dimension related to other dimensions', and students learn about (a) the sustainable social, economic and cultural development of the local environment and environment of Croatia, Europe and the world; (b) the right to a healthy environment and sustainable development of the community; (c) the influence of economics, science, culture and politics on environment; and (d) the role of individuals and civil society in ensuring sustainable development.

\subsubsection{The Case of the Netherlands}

Before discussing the Dutch case on the inclusion of Environmental Citizenship and Education for Environmental Citizenship in secondary schools, the educational system needs to be elucidated. The Dutch secondary education system (ages 12-18) is divided into four main tracks: (a) preuniversity education (6 years); (b) general secondary education (5 years); (c) pre-vocational education (4 years); and (d) vocational training programme (4 years). Each level provides access to different higher education institutes: university (a), higher professional education (b), senior secondary vocational education (c and d), and each track has its specific national examination requirements: the formal curriculum (CvTE 2016a).

Overall, sustainability and citizenship education are quite well represented in preuniversity and general secondary education tracks of the Dutch secondary school curricula, but not specifically referred to as Environmental Citizenship or Education for Environmental Citizenship. The Biology and Chemistry curricula in these two tracks prescribe content-specific requirements related to sustainability such as human influence on energy preservation and sustainable production processes. 
Moreover, the formal curricula include sustainability as a context in which students should be able to reason in, for instance, the interaction of ecosystems, biodiversity, food production and energy conversion, which is more in line with a Future 1 perspective on education. Remarkably, the examination requirements for physics do not include the word or theme of sustainability or Environmental Citizenship at all, although teachers indicate they often teach subjects in the context of sustainability, such as solar cells, wind turbines and nuclear energy. The formal curricula for the pre-vocational education and the vocational training programme tracks have only very limited references to Environmental Citizenship or Education for Environmental Citizenship, one sentence stating such a reference is: 'to pay attention to the relation between human and nature and the concept of sustainable development' (CvTE 2016 b, p. 1). However, the attainment targets for lower secondary education the 'Kennisbases' ('Knowledge base') - which crosscut the different tracks - include sustainability thinking ('denkwijze duurzaamheid') as a specific way of thinking to the science curriculum.

The importance of citizenship education for sustainability is also reflected by the Dutch national science curriculum for both lower and upper secondary education. Next to content-specific examination requirements, a more overarching competence is included in all science subjects (Biology, Chemistry and Physics) since 2016, similar to the 'Working Scientifically' tenet of the English National Curriculum for Science. The curricular examination requirement A9 'waarderen en oordelen' ('to value and evaluate') asks for the evaluation of situations in nature and technological applications, using scientific arguments, normative considerations and personal opinions (CvTE 2016c, p. 3; 2016d, p. 3; 2016e, p. 3). Here, we can see a more Future 2-based curriculum aiming for socialisation and subjectification (Biesta 2015) more in line with the goals of Environmental Citizenship and Education for Environmental Citizenship. The flip side of these more overarching general competences is that these are either not assessed in the national examination or they are assessed to a lesser extent. As a result, the attention paid to these skills in classroom practice largely depends on policies of individual schools and teachers. This is underlined by a comprehensive study initiated by the government on the status quo of education for sustainable development in the Netherlands. This study reports that one of the areas where the Netherlands is performing well (in an international perspective) is taking an integrated approach to education for sustainable development (Het Groene Brein 2015). However, for formal secondary education, support for schools to move forward on this topic is limited, and structural implementation in teaching is far from optimal. Since 2014, the attention on education for sustainable development has increased. This was initiated especially by Dutch youth organisations involved in the process of ensuring proper integration of sustainability in school curricula. This attention on sustainability is reflected by the increasing awareness on citizenship education at the national level as well (Platform Onderwijs2032 2016) and has made the curriculum more future-proof. Since 2018, national teacher teams and school leaders have updated the curricula for the different domains in secondary education. The outcomes and suggestions will be presented to the government in 2019. 


\subsection{Teaching Approaches for Environmental Citizenship}

Several educational approaches can serve as an answer to the requirements for a Future 2 education. In the context of non-formal education (Chap. 14), pedagogies have been described that can also be included in formal settings. These include place-based education, civic ecology education, ecojustice pedagogy, action competence, socio-scientific inquiry-based learning and pedagogies that could build student competencies for civic participation contributing to environmental and social change. Here, we elaborate one approach that is only briefly described in Chap. 14 - Socio-Scientific Inquiry-Based Learning (SSIBL) - since it has been extensively evaluated in formal secondary science education settings (in addition to primary education) as well as teacher professional development programmes in 11 countries (www.parrise.eu). SSIBL integrates educational approaches that are often presented independently in schools: inquiry-based science education and citizenship education. Integration of these approaches has been inspired by the European Union call for an ongoing involvement of the society in all phases of the research and innovation process (European Commission 2019). For Science, Technology, Engineering and Mathematics (STEM) education, this calls for the integration of both inquiry-based science education and citizenship education in the curriculum and classroom.

Inquiry-based science education is a problem-based approach with an emphasis given to experiment (Rocard et al. 2007). Methods for inquiry-based science education provide children with the opportunities to develop a large range of complementary skills such as working in groups, being able to express themselves textually and verbally, and experiencing open-ended problem-solving and other cross-disciplinary skills (Rocard et al. 2007). This call for inquiry-based science education is based on the recognition that science is essentially a question-driven, open-ended process and that students must have personal experience of scientific inquiry to understand this fundamental aspect of science. The understanding of inquiry is guided by five essential features of inquiry that have been recognised by the US National Research Council (2000), which state that the learner (a) engages in scientifically oriented questions; (b) gives priority to evidence in responding to questions; (c) formulates explanations from evidence; (d) connects explanations to scientific knowledge; and (e) communicates and justifies explanations. Learning and teaching about inquirybased science education can be seen as a continuum beginning with close-ended and ending with open-ended inquiry.

SSIBL is a recently developed approach and combines inquiry-based science education with citizenship education, starting from socio-scientific issues. This approach has been evaluated extensively in science teacher professional development, as well as in classroom settings (Amos et al. in press; Knippels and van Harskamp 2018; Levinson 2018; Levinson et al. 2017). Socio-scientific issues such as global warming - are problems that often arise in our society and have a scientific and/or a technological component. They are issues or problems because there is no consensus on how such problems might best be solved for the well-being 
of individuals and the society more broadly, and therefore they have inherent moral and ethical components (Sadler 2011; Ratcliffe and Grace 2003). To be able to deal with these types of issues, students have to know how to recognise and interpret data, understand how different social factors can have different effects and understand that stakeholders often have diverging opinions (Sadler 2004). Examples of socio-scientific issues concerning environmental education are the deployment of alternative energy resources, the environmental effects caused by the production of socially useful materials or the climate effects as a result of increased carbon dioxide emissions.

Through socio-scientific issues, the approach of SSIBL introduces the socioinquiry at school. According to Levinson (2018, p.31), this is core to this approach: 'Inquiry means to ask questions and seek insights into problems that intrigue us. These questions can be broad but also focused. They can arise from curiosity about natural phenomena, or be more socially-oriented. What's inside bubbles? Do birds sleep? Is chocolate bad for you? Is cycling to school really healthier than going by car? Are new technologies all they claim to be? SSIBL is therefore different from regular forms of scientific inquiry in schools because it is based on scientific methods and social considerations'. The core idea of citizenship education in SSIBL is to participate critically in taking action. With this approach, students can argue a point with personal commitment, using evidence and reason and listen carefully and considerately to what others have to say. The approach promotes respect for the views of others and to have an open mind; if a fellow student advances a better argument, one can judge it on its merits (Levinson et al. 2012).

Teaching SSIBL has three main stages: authentic questions (Ask), exploration (Find out) and action (Act). A classroom activity could start with raising meaningful and authentic questions (Ask) about socio-scientific issues (see Fig. 13.1, retrieved from Levinson et al. (2017); Amos et al. in press). To explore these questions, social and scientific inquiry is used (Find out). Finally, students are stimulated to form opinions and formulate solutions (Act). However, this model does not necessarily have to be followed sequentially. For example, 'Ask' might arise from an investigation to 'Find out'.

The three main stages of SSIBL (Ask, Find out, Act) can be introduced in classroom settings with the help of educational phases that have been implemented and evaluated in teacher professional development sessions and lesson designs, with the aim of critical and democratic citizenship in science education (Knippels and van Harskamp 2018):

1. Introduction of dilemma: connect to student's daily life, interest

2. Initial opinion-forming (individually or in small groups)

3. Raise questions: 'need to know' (e.g. content related, social and/or personal questions)

4. Inquiry: students answering the questions raised through social, personal and scientific inquiry

5. Dialogue: value communication and clarification

6. Decision-making: formulate solutions that help to enact change 


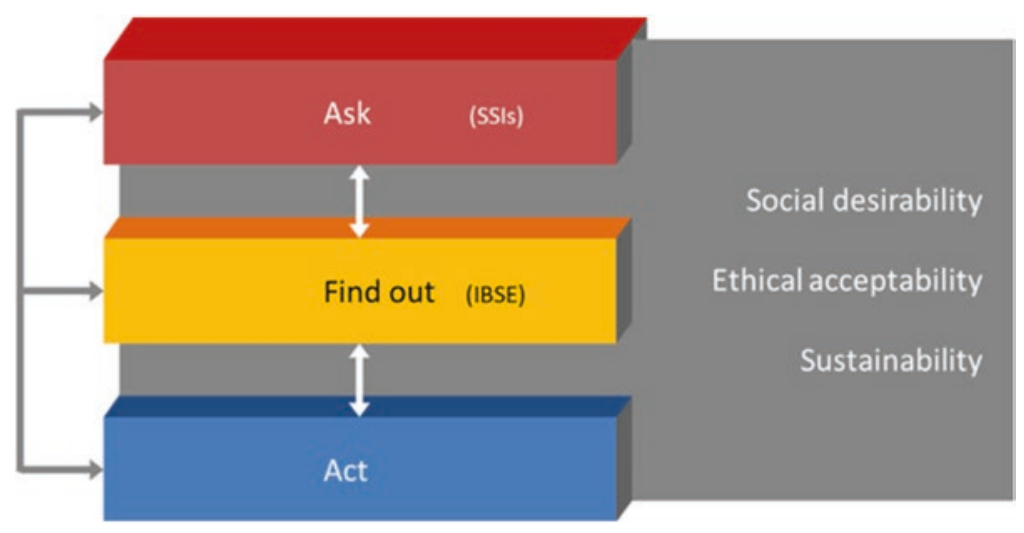

Fig. 13.1 Stages of the SSIBL model. (Retrieved from Levinson et al. 2017; Amos et al. in press)

\section{Reflection: on student's opinion-forming process (metacognition)}

Here, we will provide one example of a typical case for SSIBL outlined by RomeroAriza and colleagues (2018). In this Spanish case, secondary school students studied whether pangasius fish should be sold in supermarkets and stores ('Ask'). Guided by supporting questions, teams of 3-4 students studied the various arguments for or against pangasius sales, ranging from environmental to health and socio-economic arguments. Environmental arguments concerned the conditions of pangasius fish farming in Vietnam, over-exploitation and the impact on the environment. Subsequently, these arguments were exchanged and discussed in a classroom debate. One of the main outcomes was that the actual toxicity of pangasius consumption, obtained from scientific sources, was not in accordance with media coverage where the fish was depicted as 'poisonous' ('Find out'). The school students undertook actions, which ranged from personal decisions on whether to keep on eating pangasius fish to recommendations to the school canteen or to other supermarket chains, based on the outcomes of their inquiry ('Act'). The authors concluded that 'Such actions enhance the sense of ownership and empowerment and give a sense of purpose to the learning taking place' (Romero Ariza et al. 2018, p. 43-44).

Based on this overview, we would argue that SSIBL is a pedagogy that can foster democratic citizenship in general, and Environmental Citizenship in particular. Therefore, we would suggest that this teaching approach would be well suited for the implementation of Education for Environmental Citizenship in formal secondary education. In order to accomplish this aim, it is important to engage teachers on different subjects in Education for Environmental Citizenship. One way of doing this is through teacher professional development programmes. The SSIBL approach to teaching has been introduced to several hundreds of teachers in 11 different countries in the PARRISE project via a systematic use of professional development training (www.parrise.eu). In the programmes the same approach can be used but adopted to local contexts and conditions of various countries and school forms. For 
example, in a professional development programme at the Weitzman institute in Rehovet, Israel, the three-stage model of SSIBL was used to teach investigate inquiry and civilian responsibility relating to the case of placing defibrillators at public places in order to rescue fellow citizens with cardiac arrest. The teaching module was developed based on students' questions related to a known case were a football player collapsed during a game and suffered severe injuries.

Besides specially designed teacher development programmes, Education for Environmental Citizenship also needs to be enacted within the existing structures of secondary schooling. In the next section, we will investigate this issue further.

\subsection{Moving Towards Education for Environmental Citizenship in Secondary Schooling}

Many teachers around the world want to develop their teaching and work interdisciplinary, but they feel they do not have the time because they need to keep up with the curricula. A recent report on teachers' perspectives on the state of environmental education in England has identified the tension between teachers' perceptions of environmental education as a subject that can promote active Environmental Citizenship and current perceived focus of the curriculum as emphasising the learning of subject knowledge (Glackin et al. 2018). Earlier research has shown extensive differences in how teachers from different school subjects enact various aspects of Education for Environmental Citizenship, such as social or ethical topics (e.g. Levinson and Turner 2002). In some school subjects, environmental topics are marginal or absent (e.g. Mathematics, Psychology), but they have a much higher profile in others (e.g. Environmental Science, Geography) (Dawe et al. 2005). Levinson and Turner (2002) also found differences between science and humanities teachers' understanding of the aim of their teaching. Humanities teachers are more confident when covering ethical and social issues, while science teachers are more focused on presenting the 'facts' of their subject. The same can be seen relating to the use of teaching methods; Humanities teachers have been shown to use class discussions more frequently than science teachers (Oulton et al. 2004). Summers et al. (2005) also found that science teachers compared to geography teachers to lesser extent use teaching methods that are more suitable to sustainability education. Corney (2006) showed that upper secondary school trainee teachers in geography felt that they lack the necessary subject expertise to teach sustainable development. These results from various studies show that teachers of different subjects in secondary education understand and teach issues relating to the environment, sustainability and citizenship quite differently. The teachers of the various school subjects transform the curricular content in different ways, although addressing the same topic (Gericke et al. 2018).

Previous research in Sweden has shown that teachers of different school subjects and subject areas have different approaches to environmental and sustainability education. Teachers in Sweden typically teach environmental issues according to three different selective traditions (Sund and Wickman 2011). The three Swedish selective traditions are the fact-based tradition, the normative tradition and the plu- 
ralistic tradition (Sandell et al. 2005). In the fact-based tradition, environmental issues are regarded as ecological issues. Environmental problems are based on a lack of knowledge and can be solved by learning more science. In the normative tradition, environmental and developmental issues are primarily a question of values, where people's lifestyles and their consequences are the main threats to the natural world. Increased uncertainty on complex issues, such as climate change, is an important point of departure for the pluralistic tradition. Here, environmental issues are viewed as both moral and political problems, while environmental problems are regarded as conflicts between human interests.

The distribution of these three teaching traditions varies in different school subjects. For example, science teachers teach in a more fact-based way than social science and language teachers (Borg et al. 2012). Hence, student groups may encounter different teaching content and approaches between different subjects. Many school subjects are limited by the curricular goals and the organisation of education that constrain cross- and/or inter-disciplinary efforts, as shown in the cases of the different countries in this chapter. Therefore, teachers are likely to build their conceptual understanding of Environmental Citizenship and Education for Environmental Citizenship on the foundation of their own subject traditions. Education for Environmental Citizenship is multidisciplinary by nature, and this fact might be an obstacle for subject teachers, an argument supported by Stables and Scott (2002). Earlier studies have shown that if teachers have a holistic understanding of concepts, such as Environmental Citizenship, they will use a broader approach to teaching and learning, while a narrowed understanding is often associated with narrow approaches to teaching (Petocz and Reid 2002).

As shown in this and other chapters of this volume, Education for Environmental Citizenship is rooted in a Future 2 trajectory as outlined by Young and Muller (2010), and this could hinder the inclusion of Environmental Citizenship in formal secondary education. The reason is that the secondary school system of many countries is more rooted in a Future 1 trajectory focusing on disciplinary content knowledge, as has been exemplified in this chapter. However, Young and Muller (2010) argue for a third curriculum principle, a Future 3 scenario, where the "differentiatedness' of knowledge between different school subjects is recognised. This might be important for Education for Environmental Citizenship because different disciplines have different knowledge structures, for example, science and mathematics have conceptual-rich and hierarchical knowledge structures demanding a certain learning progression, while social science subjects tend to advance through variation or diversification of concepts (Young and Muller 2010). Therefore, to engage teachers of different subject specialisation, as commonly found in formal secondary education, the subject boundaries as in a Future 3 trajectory need to be kept. In that way the specialist knowledge of teachers of different disciplines can be used in Education for Environmental Citizenship. The difference from a Future 1 perspective is that the boundaries between the subjects, i.e. how the concepts are interpreted differently in different disciplines, how various disciplines generate new knowledge differently and how their ontological and epistemological starting points might differ, are all made explicit and problematised in a Future 3 perspective. Hence, in 
implementing Education for Environmental Citizenship in formal secondary education, it is important that different disciplines contribute their different disciplinary perspectives in order to give a more holistic view of Environmental Citizenship instead of merely teaching the same thing in different classrooms.

As shown in this chapter, teaching Environmental Citizenship in formal secondary education is a task for teachers of different disciplines, and they need to be able to work together for that effort. One way of coping with the multidisciplinary issues of Education for Environmental Citizenship is to organise teaching through teams of teachers representing different school subjects. However, as shown from largescale studies, cross-disciplinary work including teachers from different subjects is not commonly used by secondary schoolteachers when teaching on sustainability issues (Borg et al. 2012). There might be institutional obstacles to overcome, such as scheduling, exam and tests in the subjects, teaching traditions, etc. Fullan (2001) found that teachers are heavily affected by the school organisation and the norms, values and structures of the school in which they are working. These factors will have a huge effect on how individual teachers teach. If they were to work together in teams to implement Education for Environmental Citizenship, it is important that working this way becomes part of the regular school culture.

An important issue to address is what should this teamwork look like? Should it be based on interdisciplinary or multidisciplinary teaching? Multidisciplinary teaching is a cooperation without common aims, while interdisciplinary collaborations have a more coherent common mission (Blaye et al. 1991). Collaboration across subjects and subject areas in a school context is often referred to as crosscurricular teaching (Hudson 1995). Another important issue to address is then the differences in the subject areas contributing to Education in Environmental Citizenship in terms of the content, methods and purposes that students encounter in teaching. In what way is it possible to organise education in order to facilitate teaching approaches such as SSIBL described in this chapter, or other approaches like place-based education, civic ecology education, ecojustice pedagogy, etc., as outlined in Chap. 14. There are two different ways of understanding cross-curricular work in practice between different teacher groups: co-operation and collaboration as illustrated in Fig. 13.2 (Sund and Gericke n.d.).

In Fig. 13.2, a representation is shown of how three different school subjects cooperate on a common theme such as Environmental Citizenship but offer their own specific knowledge, teaching methods and perspectives to students. Hence, the teachers bring in their respective disciplinary perspectives and skills that provide a broad and holistic perspective on Environmental Citizenship, but they do not overlap making it difficult for students to relate the perspectives to each other. In collaboration, some parts are common for all three subject areas relating to Environmental Citizenship, whereas other parts are specific subject contributions to Environmental Citizenship (Fig. 13.2).

We argue that the collaboration model can be considered as ideal for crosscurricular teaching within a Future 3 trajectory, because the different subject perspectives complement each other holistically, while at the same time address commonalities relating the perspectives to each other providing possibilities for 
Co-operation (multidisciplinarity)

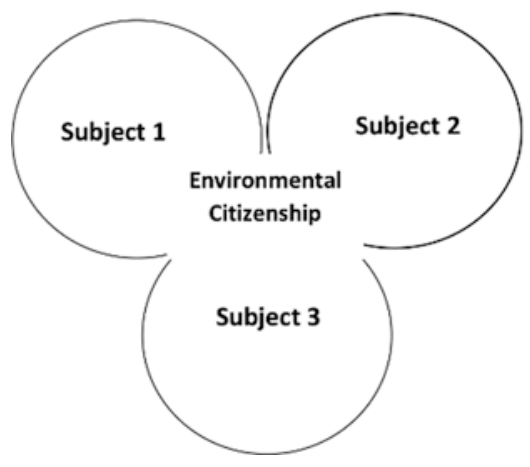

Collaboration (interdisciplinarity)

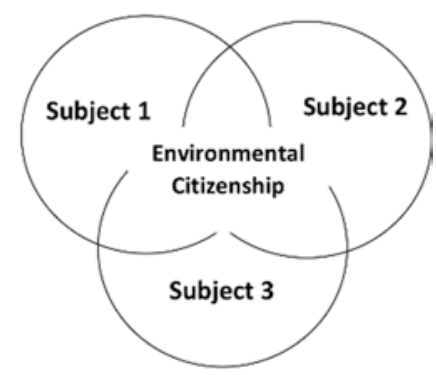

Fig. 13.2 Two ways of cross-disciplinary teaching in formal secondary education: cooperation and collaboration. (Modified from Sund and Gericke n.d.)

students' learning. This way of organising cross-curricular teaching of Education for Environmental Citizenship as a true collaboration between subject specialist teachers in formal secondary education could be a benchmark for the implementation of Environmental Citizenship in the future. It could also be a fruitful tool for identifying and developing ways by which interdisciplinary pedagogical instruction can realise the aims of Education for Environmental Citizenship. At the same time, challenges identified from a structural and policy perspective need to be addressed in order to create school cultures that can facilitate such collaborative initiates for Environmental Citizenship.

Acknowledgements This chapter is based on work from Cost Action ENEC - European Network for Environmental Citizenship (CA16229) supported by COST (European Cooperation in Science and Technology).

\section{References}

Amos, R., Knippels, M. C., \& Levinson, R. (in press). Socio-scientific inquiry-based learning: Possibilities and challenges for teacher education. In J. Dillon, M. Evagorou, \& J. A. Nielsen (Eds.), Science teacher education for responsible citizenship: Towards a pedagogy for relevance through socio-scientific issues. New York: Springer.

Biesta, G. (2015). What is education for? On good education, teacher Judgement, and educational professionalism. European Journal of Education, 50(1), 75-87.

Blaye, A., Joiner, R., \& Sheldon, S. (1991). Collaboration as a facilitator of planning and problem solving on a computer-based task. British Journal of Developmental Psychology, 9, 471-483.

Borg, C., Gericke, N., Höglund, H., \& Bergman, E. (2012). The barriers encountered by teachers implementing education for sustainable development: Discipline bound differences and teaching traditions. Research in Science \& Technological Education, 30(2), 185-207.

Borg, C., Gericke, N., Höglund, H., \& Bergman, E. (2014). Subject-and experience-bound differences in teachers' conceptual understanding of sustainable development. Environmental Education Research, 20(4), 526-551. 
CoE. (2018). Reference framework of competences for democratic cultures. Strasbourg: Council of Europe Publishing.

College voor Toetsen en Examens (CvTE). (2016a). Examenblad 2019. Available at: https://www. examenblad.nl/. Last accessed on 6 Feb 2019.

College voor Toetsen en Examens (CvTE). (2016b). Examenprogramma biologie VMBO [Examination program biology vocational track] Available at: https://www.examenblad.nl/examenstof/biologie-vmbo-2/2019/f=/biologie.pdf. Last accessed on 6 Feb 2019.

College voor Toetsen en Examens (CvTE). (2016c). Examenprogramma biologie VWO [Examination program Biology pre-university track]. Available at: https://www.examenblad. nl/examen/biologie-vwo-2/2019. Last accessed on 6 Feb 2019.

College voor Toetsen en Examens (CvTE). (2016d). Examenprogramma Scheikunde VWO [Examination program Chemistry pre-university track]. Available at: https://www.examenblad. nl/examen/scheikunde-vwo-2/2019. Last accessed on 6 Feb 2019.

College voor Toetsen en Examens (CvTE). (2016e). Examenprogramma Natuurkunde VWO [Examination program Physics pre-university track]. Available at: https://www.examenblad.nl/ examenstof/natuurkunde-vwo-2/2019/f=/examenprogramma_natuurkunde_vwo_2015_2016. pdf. Last accessed on 6 Feb 2019.

Corney, G. (2006). Education for sustainable development: An empirical study of the tensions and challenges faced by geography student teachers. International Research in Geographical and Environmental Education, 15(3), 224-240.

Dawe, G., Jucker, R., \& Martin, M. (2005). Sustainable development in higher education: Current practice and future developments. New York: Higher Education Academy.

Department for Education (DfE). (2013a). National curriculum in England: Citizenship programmes of study for key stages 3 and 4. Available at: https://www.gov.uk/government/ publications/national-curriculum-in-england-citizenship-programmes-of-study/national-curriculum-in-england-citizenship-programmes-of-study-for-key-stages-3-and-4. Last accessed on $21 \mathrm{Feb} 2019$.

Department for Education (DfE). (2013b). Geography programmes of study: Key stage 3. National curriculum in England. Available at: https://assets.publishing.service.gov.uk/government/ uploads/system/uploads/attachment_data/file/239087/SECONDARY_national_curriculum_-Geography.pdf. Last accessed on 21 Feb 2019.

Department for Education (DfE) (2015). National curriculum in England: Science programmes of study. Available at: https://www.gov.uk/government/publications/national-curriculum-inengland-science-programmes-of-study/national-curriculum-in-england-science-programmesof-study. Last accessed on 21 Feb 2019.

Dobson, A. (2007). Environmental citizenship: Towards sustainable development. Sustainable Development, 15(5), 276-285.

European Commission. (2019). Responsible research \& innovation. https://ec.europa.eu/programmes/horizon2020/en/h2020-section/responsible-research-innovation\#Article. Last accessed on 15 Jan 2019.

European Commission/EACEA/Eurydice. (2017). Citizenship education at School in Europe 2017. Eurydice report. Luxembourg: Publications Office of the European Union.

Fullan, M. (2001). The new meaning of educational change. London: Routledge Falmer.

Gericke, N., Hudson, B., Olin-Scheller, C., \& Stolare, M. (2018). Powerful knowledge, transformations and the need for empirical studies across school subjects. London Review of Education, $16(3), 428-444$.

Glackin, M., \& King, H. (2018a). But don't they teach that in geography?': The state of environmental education in secondary schools in England. Education in Science, 274, 12-13.

Glackin, M., \& King, H. (2018b). Understanding environmental education in secondary schools in England: Perspectives from policy (report 1). London: King's College London.

Glackin, M., King, H., Cook, R., \& Greer, K. (2018). Understanding environmental education in secondary schools in England: The practitioners' perspective (report 2). London: King's College London. 
Het Groene Brein. (2015). Rapportage onderzoek duurzaam onderwijs. In opdracht van Ministerie van Infrastructuur en Milieu, Uitgevoerd door Het Groen Brein, 1-86) [Het Groene Brein (2015). Report sustainable education research. Commissioned by Ministry of Infrastructure and Environment, implemented by Het Groen Brein, (1-86)].

Hudson, B. (1995). Group work with multimedia in the secondary mathematics classroom. (Doctoral), Hallam University, Sheffield, UK.

Knippels, M. C. P. J., \& van Harskamp, M. (2018). An educational sequence for implementing socio-scientific inquiry-based learning. School Science Review, 100(371), 46-52.

Levinson, R. (2018). Introducing socio-scientific inquiry-based learning (SSIBL). School Science Review, 100(371), 31-35.

Levinson, R., \& Turner, S. (2002). Valuable lessons: Engaging with the social context of science in schools. The Wellcome Trust.www.wellcome.ac.uk/stellent/groups/corporatesite/@ msh_peda/documents/web_document/wtd003446.pdf. Last accessed on 18 Feb 2016.

Levinson, R., Hand, M., \& Amos, R. (2012). What constitutes high quality discussion in science? Research from the perspectives on science course. School Science Review, 93(344), 114-120.

Levinson, R., Knippels, M. C., van Dam, F., \& Kyza, E. et al. (2017). Science and society in education. Socio-scientific inquiry-based learning: Connecting formal and informal science education with society. https://www.parrise.eu/wp-content/uploads/2018/03/parrise-en-rgb.pdf. Last accessed on 15 Jan 2019.

Ministry of Science, Education and Sports (MSES). (2014). Decision on the provision of the program of inter-subject and interdisciplinary contents of citizenship upbringing and education for elementary and secondary schools, Official Gazette 104/2014.

Mogren, A., \& Gericke, N. (2017). ESD implementation at the school organization level, part 1 - Investigating the quality criteria guiding school leaders' work at recognized ESD schools. Environmental Education Research, 23(7), 972-992.

Mogren, A., Gericke, N., \& Scherp, H.-Å. (2019). Whole school approaches to education for sustainable development: A model that links to school improvement. Environmental Education Research, 25(4), 508-531.

National Center for External Evaluation of Education (NCEEE). (2015). Curriculums for gymnasiums and vocational secondary schools. Available at: https://www.ncvvo.hr/nastavni-planovii-programi-za-gimnazije-i-strukovne-skole/. Last accessed on 18 Nov 2018.

National Research Council. (2000). Inquiry and the National Science Education Standards: A guide for teaching and learning. Washington, DC: The National Academies Press.

Oulton, C., Day, V., Dillon, J., \& Grace, M. (2004). Controversial issues: Teachers' attitudes and practices in the context of citizenship education. Oxford Review of Education, 30(4), 489-507.

Pallett, H. (2017). Environmental citizenship. In D. Richardson, N. Castree, M. F. Goodchild, A. Kobayashi, W. Liu, \& R. A. Marston (Eds.), International encyclopedia of geography: People, the earth, environment and technology. Chichester: Wiley.

Petocz, P., \& Reid, A. (2002). Enhancing learning using generic and specific aspects of knowledge formation. In A. Goody \& D. Ingram (Eds.), Spheres of influences: Ventures and visions in educational development (pp. 1-10). Crawley: University of Western Australia. www.csd.uwa. edu.au/ICED2002/publication/. Last accessed on 18 Feb 2016.

Platform Onderwijs2032. (2016). Ons Onderwijs 2032, Eindadvies. Uitgave door Platform Onderwijs2032, in opdracht van de staatssecretaris van Onderwijs, Cultuur en wetenschap. Den Haag. ISBN/EAN 978-90-824928-0-4. [Platform Onderwijs2032 (2016). Our Education 2032. Final advise. Publication by Platform Onderwijs2032, commissioned by the State Secretary for Education, Culture and Science. The Hague. ISBN/EAN 978-90-824928-0-4.

Ratcliffe, M., \& Grace, M. (2003). Science education for citizenship. Teaching socio-scientific issues. Maidenhead/Philadelphia: Open University Press.

Rocard, M., Csermely, P., Jorde, D. et al. (2007). Science education now: A renewed pedagogy for the future of Europe. http://ec.europa.eu/research/science-society/document_library/pdf_06/ report-rocard-on-science-education_en.pdf. Last accessed on 10 Feb 2019.

Romero Ariza, M., Abril, A., \& Quesada, A. (2018). Empowering teachers to bring authenticity and responsive action into the science classroom. School Science Review, 100(371), 40-45. 
Sadler, T. D. (2004). Informal reasoning regarding socioscientific issues: A critical review of research. Journal of Research in Science Teaching, 41, 513-536.

Sadler, T. D. (2011). Socio-scientific issues in the classroom: Teaching, learning and research. Dordrecht: Springer.

Sandell, K., Öhman, J., \& Östman, L. (2005). Education for sustainable development. Lund: Studentlitteratur.

Schulz, W., Ainley, J., Fraillon, J., Kerr, D., \& Losito, B. (2010). ICCS 2009 International report: Civic knowledge, attitudes, and engagement among lower-secondary school students in 38 countries. Amsterdam: International Association for the Evaluation of Educational Achievement (IEA).

Schulz, W., Ainley, J., Fraillon, J., Losito, B., \& Agrusti, G. (2016). IEA International Civic and Citizenship Education Study 2016: Assessment framework. Amsterdam: International Association for the Evaluation of Educational Achievement (IEA).

Schulz, W., Ainley, J., Fraillon, J., Losito, B., Agrusti, G., \& Friedman, T. (2017). Becoming Citizens in a Changing World. IEA International Civic and Citizenship Education Study 2016 International Report. Amsterdam: International Association for the Evaluation of Educational Achievement (IEA).

Stables, A., \& Scott, W. (2002). The quest for holism in education for sustainable development. Environmental Education Research, 8(1), 53-60.

Summers, M., Childs, A., \& Corney, G. (2005). Education for sustainable development in initial teacher training: Issues for interdisciplinary collaboration. Environmental Education Research, 11(5), 623-647.

Sund, P., \& Wickman, P.-O. (2011). Socialization content in schools and education for sustainable development - I. a study of teachers' selective traditions. Environmental Education Research, 17(5), 599-624.

Sund, P., \& Gericke, N. (n.d.). Teaching contributions from three different secondary school subject areas to education for sustainable development. Manuscript in preparation.

Sundberg, D. (2005). Skolreformernas dilemman - en läroplansteoretisk studie av kampen om tid I den svenska obligatoriska skolan [Dilemmas of school reforms - A theoretical curriculum study of the struggle for time in compulsory School in Sweden]. Växjö: Växjö Universitet.

Young, M. (2015). Powerful knowledge as curriculum principle. In M. Young, D. Lambert, C. R. Roberts, \& M. D. Roberts (Eds.), Knowledge and the future school: Curriculum and social justice (2nd ed., pp. 65-88). London: Bloomsbury Academic.

Young, M., \& Muller, J. (2010). Three educational scenarios for the future: Lessons from the sociology of knowledge. European Journal of Education, 45, 11-27.

Open Access This chapter is licensed under the terms of the Creative Commons Attribution 4.0 International License (http://creativecommons.org/licenses/by/4.0/), which permits use, sharing, adaptation, distribution and reproduction in any medium or format, as long as you give appropriate credit to the original author(s) and the source, provide a link to the Creative Commons license and indicate if changes were made.

The images or other third party material in this chapter are included in the chapter's Creative Commons license, unless indicated otherwise in a credit line to the material. If material is not included in the chapter's Creative Commons license and your intended use is not permitted by statutory regulation or exceeds the permitted use, you will need to obtain permission directly from the copyright holder.

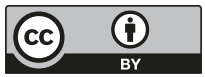

